ZOOLOGIA 30 (6): 585-591, December, 2013

http://dx.doi.org/10.1590/S1984-46702013005000013

\title{
Coordinated feeding behavior of the Guiana dolphin, Sotalia guianensis (Cetacea: Delphinidae), in southeastern Brazil: a comparison between populations
}

\author{
Elaine C. da S. Oliveira' ${ }^{1,2}$, Rodrigo H. Tardin' ${ }^{1}$, Fabiana R. Poletto ${ }^{1}$ \& Sheila M. Simão \\ ${ }^{1}$ Laboratório de Bioacústica e Ecologia de Cetáceos, Departamento de Ciências Ambientais, Universidade Federal Rural do \\ Rio de Janeiro. Rodovia BR $465 \mathrm{~km}$ 7, 23890-000 Seropédica, RJ, Brazil. \\ ${ }^{2}$ Corresponding author: E-mail: laine.csoliveira@gmail.com
}

\begin{abstract}
The coordinated feeding tactics used by delphinids are influenced by differences in the distribution of prey species, season, and opportunities for social learning. In the present study, we compared the coordinated feeding behavior of two populations of the Guiana dolphin, Sotalia guianensis, in southeastern Brazil, and how these feeding tactics vary seasonality and in the presence of calves. We observed eight types of coordinated feeding tactics, which differed in frequency and in the mean number of individuals engaged in them, and between both areas. Feeding tactics used to herd and capture prey were the most frequent and engaged a greater number of individuals, suggesting that these tactics are better for capturing fish that gather in larger schools. Furthermore, the seasons influenced the occurrence of different prey items, which in turn modified the feeding tactics of the dolphins. In the Ilha Grande Bay we observed that bouts lasted longer and larger groups engaged in the feeding tactics, which may be associated with the seasonal spawning of larger schooling fish such as Sardinella brasiliensis (Steindachner, 1879) (Teleostei: Clupeidae). However, in the Sepetiba Bay, we observed longer feeding bouts and a smaller number of individuals engaged in the feeding tactics during autumn-winter. This may be associated with the fact that the most abundant prey species, Micropogonias furnieri (Desmarest, 1823) (Teleostei: Sciaenidae), gathers in small schools. Calves were present in $95 \%$ of all coordinated feeding tactics that occurred in the Ilha Grande Bay and in approximately $61 \%$ of feeding tactics in the Sepetiba Bay, suggesting that these areas are important for social learning. This study provides more information about feeding tactics and improves knowledge of the coordinated behavior of Sotalia guianensis (Van Benéden, 1864).

KEY WORDS. Cetaceans; coordinated hunt; feeding tactics; prey; social behavior.
\end{abstract}

Cooperative feeding behavior has been reported for several cetaceans in different habitats, for instance killer whales Orcinus orca (Linnaeus, 1758) (BAIRD 2000), common dolphins Delphinus delphis (Linnaeus, 1758) (Neumann \& Orams 2003) and bottlenose dolphins Tursiops truncatus (Montagu, 1821) (BeL'Kovich et al.1991). Despite the many studies conducted with Sotalia guianensis (Van Bénéden, 1864) (e.g., Geise et al. 1999, Rossi-Santos et al. 2007), there is little information about the feeding behavior tactics used by this species or the participation of calves and group size in each tactic (RossI-SANTOS \& FLORES 2009, TARDin et al. 2011). The Guiana dolphin S. guianensis is a small delphinid that occurs continuously along the Atlantic coast of Central and South America, from Nicaragua to the state of Santa Catarina, southern Brazil, inhabiting estuaries and bays (SimÕes-Lopes 1998, CARr \& Bonde 2000). It usually forms small groups (1 to 30 individuals) (e.g., Geise 1991). According to FloREs \& DA Silva (2009), large groups are usually engaged in feeding activities. Some studies on the diet of this species along the Brazilian coast indicate that the feeding hab- its of this dolphin are opportunistic and generalist at different depths (e.g., Oliveira et al. 2008). The main food items consumed by the Guiana dolphin are pelagic or demersal prey, for instance Sardinella brasiliensis (Steindachner, 1879) (Teleostei: Clupeidae), Trichiurus lepturus (Linnaeus, 1758) (Teleostei: Trichiuridae) and Micropogonias furnieri (Desmarest, 1823) (Teleostei: Sciaenidae) (Di BeneditTo \& Ramos 2004), which inhabit estuarine waters (e.g., Borobia \& Barros 1989, Araújo et al. 1998).

This study compares the coordinated feeding behavior of $S$. guianensis in two bays in southeastern Brazil. First, we describe and quantify the feeding tactics and dolphin group size in each tactic for each area. Then, we compare the results between the two areas. Because dolphins use different feeding tactics to capture fish in different school sizes, they are likely to gather in different numbers according to the size of the school. Furthermore, in order to test whether dolphins spend more time feeding in any particular season, we analyze whether the duration of the feeding behavior (bout) varies seasonally, 
and associate our results with the seasonal spawning and abundance of prey, for instance $S$. brasiliensis. Finally, we also ascertain the participation of calves and juveniles in each tactics, in each bay.

\section{MATERIAL AND METHODS}

Along the southern coast of Rio de Janeiro, a large estuarine systems is formed by the Ilha Grande, $22^{\circ} 50^{\prime}-23^{\circ} 20^{\prime} \mathrm{S}$, $44^{\circ} 00^{\prime}-44^{\circ} 45^{\prime} \mathrm{W}$, and the Sepetiba bays, $22^{\circ} 54^{\prime}-23^{\circ} 04^{\prime} \mathrm{S}, 43^{\circ} 34^{\prime}-$ $44^{\circ} 10^{\prime} \mathrm{W}$ (Fig. 1) (Signorini 1980, Araújo et al. 1998). The Ilha Grande Bay receives deep waters rich in nutrients, derived from the South Atlantic Central Waters (SACW) (SIGNORINI 1980), and organic matter from river drainage and mangrove production, which act as a transition area between the sea and the land (Nogara 2000). We surveyed the western area, which includes shallow waters $(\leqslant 10 \mathrm{~m})$, using boats. The Sepetiba Bay is a semi-enclosed body of water connected with the sea in the East, by a small, shallow inlet with little water flow, which crosses extensive mangrove forests. Much of the inlet complex is shallow (about $6 \mathrm{~m}$ in depth). In some areas, however, as in between islands, it may reach $47 \mathrm{~m}$ in depth. There is a large natural channel in the western part that runs between the large islands of Jaguanum and Itacuruça, with depths of $\geqslant 30 \mathrm{~m}$ (Muehe \& Valentini 1998).

Sotalia guianensis occurs in protected areas, like estuaries, bays, shallow areas and areas with mangroves (Rossi-SANTOS \& Wederin 2006, Flores \& Da Silva 2009). In both Ilha Grande and Sepetiba bays, Guiana dolphin populations are present throughout the year, and most groups are composed of mothercalf pairs accompanied by juveniles (LODI 2003, NeRY et al. 2008). At the Ilha Grande Bay, LoDI (2003) observed 1,754 individuals in 54 groups; calves were present in $89 \%$ of the groups and juveniles in $87 \%$ (LODI 2003). In a recent study (TARDIN et al. 2013a) observed that $94 \%$ of the groups have calves and/or juveniles. In the Sepetiba Bay, the population size is approximately 1,269 individuals (Flach et al. 2008), and calves are present in $80 \%$ of the groups.

The present study compares the coordinated feeding tactics of the Guiana dolphin between the two populations. The data obtained from the Sepetiba Bay were collected from September 2000 to August 2001, and resulted from 29 boat trips. During the latter, we observed the general behaviors of the dolphins. The data from the Ilha Grande Bay were obtained by TARDIN et al. (2011) in the western part of it. They conducted eighteen days of boat trips from May 2007 to March 2008. Despite the fact that data from different bays were collected at different periods, the natural and anthropogenic conditions found in both areas were similar and did not influence the results. In both areas, all boat trips were conducted in random routes using a boat with $7.5 \mathrm{~m}$ and 2 observers following focal group procedures with continuous sampling (ALTMANN 1974), using SONY ${ }^{\circledR}$ Digital $825 \mathrm{x}$ and GRADIENTE ${ }^{\circledR}$ VHS $18 \mathrm{x}$ video

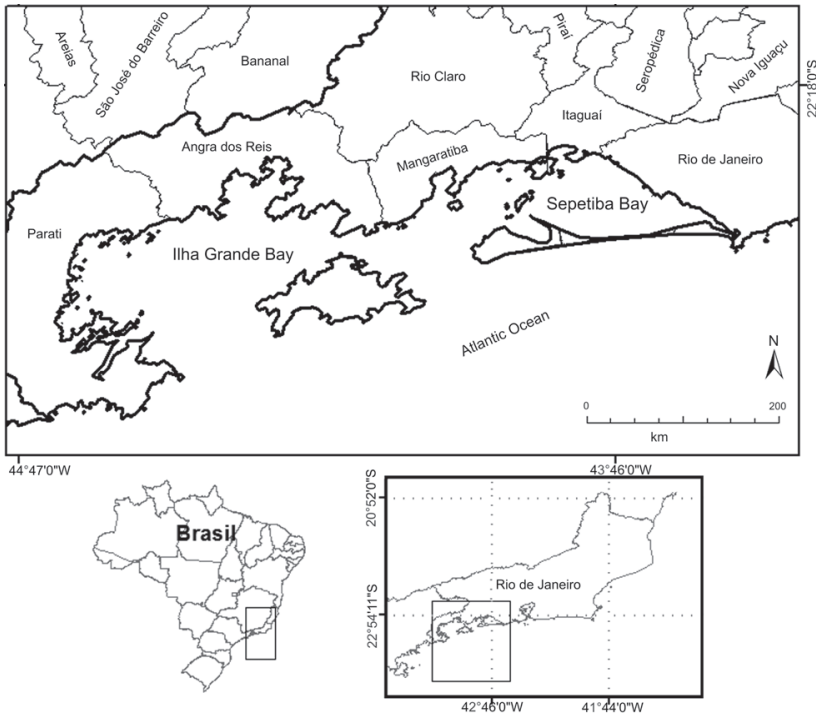

Figure 1. Map of study area, the great complex estuarine formed by Ilha Grande Bay and Sepetiba Bay, southeastern Brazil.

cameras in the Sepetiba Bay and a digital Handycam SONY ${ }^{\circledR}$ $25 \mathrm{x}$ in the Ilha Grande Bay. When we sighted a group of dolphins, we reduced the speed of the boat in order to maintain a $15 \mathrm{~m}$ distance from it, a procedure adopted also by TARDIN $e t$ al. 2013b. This distance avoids interference on the behavior of the dolphins. According to Karcmarski et al. (2000), the feeding behavior of dolphins is characterized by frequent and asynchronous dives in different directions, without a breathing pattern. We only included, in our data, dolphins that seemed to be feeding in groups.

The following definitions are used in this study: 1) Group: characterized by individuals within $10 \mathrm{~m}$ of each other (SMOlKer et al. 1992) and engaged in the same activity or moving in the same direction (SHANe 1990); 2) Feeding bout: a discrete and continuous period of feeding (in seconds), in which some feeding tactics occur (VAUGHN et al. 2008); 3) Immature individuals: calves are individuals smaller than $1 / 2$ of the adult length and are a light gray in color; and juveniles are individuals larger than $1 / 2$ and smaller than $2 / 3$ of the adult in length (GeIse et al.1999); and 4) Tactics: short-duration behaviors within each feeding bout (Altmann 1974). We classified the feeding tactics into eight categories (Table I).

Two experienced observers analyzed the video clips to avoid possible errors in identifying the tactics used by dolphin groups. First, we quantified the frequency of tactics performed by dolphins for each area separately. We counted the number of individuals in the group engaged in each tactics and the corresponding season (divided in spring-summer (September $21^{\text {st }}$ March $20^{\text {th }}$ ) and autumn-winter (March $21^{\text {st }}-$ September $\left.20^{\text {th }}\right)$ ). Then, we counted the duration of each feeding bout and the number of individuals engaged in each tactic during all survey 
Table I. Description of the eight categories of feeding tactics.

\begin{tabular}{|c|c|}
\hline Coordinated Feeding Tactic & Description \\
\hline Wall formation & $\begin{array}{l}\text { Characterized by the division of a group into two subgroups that swim } \\
\text { in opposite directions (BЕL'коVICH et al. 1991) }\end{array}$ \\
\hline Wall formation with jumps & One or both subgroups jump before or after performing the Wall formation tactic \\
\hline Perpendicular feeding & A group of dolphins split into two subgroups, which swim in perpendicular directions (TARDIN et al. 2011) \\
\hline Perpendicular feeding with jumps & One or both subgroups jump before or after performing the Perpendicular feeding tactic \\
\hline Line abreast & $\begin{array}{l}\text { Dolphins that swim side by side form a tight line, separated by no more than one dolphin-body width (NEUMANN \& } \\
\text { OrAMs 2003) }\end{array}$ \\
\hline Line abreast with jumps & One or both subgroups jump before or after performing the Line abreast \\
\hline Kettle & $\begin{array}{l}\text { Characterized by dolphins diving under a school of fish and forcing it to the surface, with dolphins emerging from } \\
\text { several directions (BЕL'KоVICH et al.1991) }\end{array}$ \\
\hline Kettle with jumps & One or both subgroups jump before or after performing Kettle \\
\hline
\end{tabular}

days in each area. To standardize the feeding bout data between the two bays, we divided the duration of each bout by the mean duration of all bouts for each area separately. Furthermore, we investigated whether the occurrence of jumps in tactics varied throughout the entire sampling period. We evaluated the presence of calves and juveniles in feeding behaviors by counting the groups containing these individuals in the two bays, their presence in the tactics and the frequency of each age class.

We used the non-parametric Mood's Median test to evaluate whether the group size in each tactic differed significantly in both areas and to assess the statistical significance between the duration of bouts in each season in both areas. The KruskalWallis test was used to determine whether the number of individuals engaged in each tactic was statistically different between the seasons for both areas. A Chi-square test was used 1) to test whether the occurrence of jumps in tactics varied during the sampling period, because some authors discuss jumping within the context of a feeding strategy (e.g., Würsig \& WürsIG 1980, Acevedo-Gutierrez 1999, Lusseau 2006, Rossi-Santos \& Flores 2009, Nascimento \& Nascimento 2010); 2) to evaluate the frequency of the main tactics; and 3) to test for the presence of immature individuals in each tactic in both areas.

\section{RESULTS}

In the Ilha Grande Bay, we observed 1,520 groups and 914 events of coordinated feeding tactics, whereas in the Sepetiba Bay we observed 948 groups and 370 events of coordinated feeding tactics (Table II). No feeding event with only one individual was observed in either bay during the study period. Feeding tactics without jumps were more frequently observed than feeding tactics with jumps, and the difference in their frequency was significantly different $\left(\chi^{2}=16.082\right.$, d.f. $\left.=1, \mathrm{p}<0.0001\right)$.

In the analysis of the feeding tactics throughout the seasons for the two populations, we only considered feeding tactics without jumps. This decision was motivated by the number of samples of tactics with jumps, which varied significantly between seasons in both areas (jumps were more frequent in the Ilha Grande than in the Sepetiba Bay), which could affect the results. In the Ilha Grande Bay, we observed 390 events of feeding tactics in the spring-summer period and 385 occurrences in the autumn-winter period, whereas in the Sepetiba Bay, we observed 168 occurrences of feeding tactics in the spring-summer period and 179 in the autumn-winter period. A significant difference $\left(\chi^{2}=86.638\right.$, d.f. $\left.=9, p<0.0001\right)$ was found in the frequency of feeding tactics between the seasons in both areas. In the Ilha Grande Bay, wall formation and perpendicular feeding were more frequently observed in all seasons, whereas kettle and line abreast were more frequently seen in the autumn-winter period. In the Sepetiba Bay, wall formation and kettle were more frequent during the autumn-winter period, and the line abreast and perpendicular feeding were more frequent in the spring-summer period.

A significant difference in group size was found during the following feeding tactics in both populations: wall formation $\left(\chi^{2}=16.21\right.$, d.f. $\left.=1, p=0.000001\right)$ and line abreast $\left(\chi^{2}=\right.$ 15.13 , d.f. $=1, \mathrm{p}=0.000001)$. By contrast, no difference was found in the size of groups performing perpendicular feeding $\left(\chi^{2}=0.56\right.$, d.f. $\left.=1, \mathrm{p}=0.453\right)$ and kettle $\left(\chi^{2}=1.20\right.$, d.f. $=1, \mathrm{p}=$ 0.273 ) (Table II).

Group size in all coordinated feeding tactics differed significantly between the two bays ( $p=0.000001)$. Therefore, in order to verity in which feeding tactics the difference occurred, we used post hoc tests for all ranks.

Wall formation and kettle differed significantly in the mean group size in the spring-summer periods for Ilha Grande and Sepetiba $(p=0.000001$ and $p=0.01966$, respectively), between the autumn-winter period for the Sepetiba Bay and the spring-summer period for the Ilha Grande Bay $(\mathrm{p}=0.000001$ and $p=0.007076$, respectively), and between the spring-summer and autumn-winter periods for the Ilha Grande Bay ( $\mathrm{p}=$ 0.000001 for both tactics).

Line abreast and perpendicular feeding tactics differed significantly in mean group size among the spring-summer periods for both bays ( $p=0.000113$ and $p=0.000002$, respectively) and between the autumn-winter period for the Sepetiba Bay and 
Table II. Number of occurrences $(\mathrm{N})$ and group size engaged in each tactic during the two sampling periods in Ilha Grande Bay (retrieved from TARDIN et al. 2011) and Sepetiba Bay.

\begin{tabular}{|c|c|c|c|c|c|c|c|c|}
\hline \multirow{3}{*}{ Coordinated feeding tactics } & \multicolumn{4}{|c|}{ Ilha Grande Bay } & \multicolumn{4}{|c|}{ Sepetiba Bay } \\
\hline & \multicolumn{2}{|r|}{ Autumn-Winter } & \multicolumn{2}{|r|}{ Spring-Summer } & \multicolumn{2}{|r|}{ Autumn-Winter } & \multicolumn{2}{|r|}{ Spring-Summer } \\
\hline & N & $\begin{array}{c}\text { Group size } \\
\text { (Mean } \pm \text { SD) }\end{array}$ & $\mathrm{N}$ & $\begin{array}{c}\text { Group size } \\
\text { (Mean } \pm \text { SD) }\end{array}$ & $\mathrm{N}$ & $\begin{array}{c}\text { Group size } \\
(\text { Mean } \pm S D)\end{array}$ & $\mathrm{N}$ & $\begin{array}{c}\text { Group size } \\
(\text { Mean } \pm S D)\end{array}$ \\
\hline Wall formation & 181 & $2-35(8.95 \pm 4.27)$ & 194 & $3-200(21.10 \pm 19.34)$ & 106 & $2-30(8.67 \pm 4.95)$ & 92 & $2-40(11.23 \pm 7.94)$ \\
\hline Wall formation with jumps & 40 & $2-25(8.95 \pm 4.96)$ & 15 & $6-15(10.0 \pm 2.64)$ & 5 & $6-30(14.2 \pm 9.17)$ & 4 & $4-12(8.00 \pm 3.65)$ \\
\hline Perpendicular feeding & 124 & $4-25(9.67 \pm 3.68)$ & 138 & $4-50(15.71 \pm 7.74)$ & 19 & $3-16(8.63 \pm 3.53)$ & 23 & $3-30(9.86 \pm 6.82)$ \\
\hline Perpendicular feeding with jumps & 73 & $3-15(7.55 \pm 2.29)$ & 11 & $7-17(10.27 \pm 3.16)$ & 1 & $(12 \pm 0)$ & 3 & $3-11(7.33 \pm 4.04)$ \\
\hline Kettle & 46 & $2-12(5.65 \pm 1.87)$ & 34 & $3-15(7.17 \pm 2.79)$ & 29 & $2-11(5.24 \pm 2.55)$ & 15 & $2-13(5.06 \pm 3.47)$ \\
\hline Kettle with jumps & 0 & - & 0 & - & 1 & $(3 \pm 0)$ & 0 & - \\
\hline Line abreast & 34 & $4-12(6.94 \pm 2.52)$ & 24 & $4-15(8.75 \pm 3.13)$ & 25 & $2-10(5.20 \pm 2.38)$ & 38 & $2-12(5.47 \pm 2.86)$ \\
\hline Line abreast with jumps & 0 & - & 0 & - & 2 & $3-4(3.5 \pm 0.70)$ & 7 & $4-8(5.57 \pm 1.51)$ \\
\hline
\end{tabular}

the spring-summer period for the Ilha Grande Bay $(\mathrm{p}=0.000119$ and $\mathrm{p}=0.000051$, respectively). Line abreast also presented a significant difference between the autumn-winter periods for the two bays ( $\mathrm{p}=0.034459)$, whereas perpendicular feeding was significantly different between the spring-summer and autumnwinter periods of the Ilha Grande Bay ( $p=0.000001)$.

During all study periods, we observed 399 feeding bouts in the Ilha Grande Bay, with a mean duration of $67.8 \mathrm{~s} \mathrm{(60 \pm}$ $114 \mathrm{~s}$ ), ranging from $7.8 \mathrm{~s}$ to $1,266 \mathrm{~s}$. In the Sepetiba Bay, we counted 239 feeding bouts lasting $66.65 \pm 60.71 \mathrm{~s}$. The feeding bouts in the Ilha Grande Bay were longer during the springsummer period (165 $\pm 223 \mathrm{~s}$ ) than during the autumn-winter period (43.8 \pm 0.86 s). However, in the Sepetiba Bay, during the spring-summer period, the bouts were shorter ( $42.91 \pm 38.28$ s) than in the autumn-winter period $(94.03 \pm 69.79 \mathrm{~s})$. No significant difference was found between the spring-summer seasons of both areas $\left(\chi^{2}=1.36\right.$, d.f. $\left.=1 ; p=0.244\right)$, whereas the autumn-winter seasons were significantly different between both areas $\left(\chi^{2}=103.36\right.$, d.f. $\left.=1, p=0\right)$.

In the Ilha Grande Bay, immature individuals were observed in $95 \%(n=905)$ of coordinated feeding tactics. They were seem more frequently in the wall formation $(38 \%, \mathrm{n}=$ $350)$ and less frequently in the line abreast formation $(6 \%, \mathrm{n}=$ 55). In the Sepetiba Bay, this class of individuals was seen in 227 feeding tactics $(61 \%)$, more frequently in the wall formation $(66 \%, \mathrm{n}=150)$, as in the Ilha Grande Bay. However, in this area, calves and juveniles were less frequently seen in the kettle feeding tactic $(8 \%, n=18)$. The results of the Chi-square test differed significantly between the frequency of feeding tactics with the presence of immature individuals and feeding tactics with a lack of calves and juveniles in both bays $\left(\chi^{2}=\right.$ 123.201, d.f. $=1, \mathrm{p}<0.10001)$.

\section{DISCUSSION}

The feeding strategies of the small delphinid S. guianensis are considered elaborate and complex, with several patterns that are executed individually or cooperatively (MONTEIRO-FILHO 2000). These dolphins use coordinated feeding tactics to overcome prey escape strategies (MAJOR 1978).

The diet of the Guiana dolphin is composed of prey species with different habitats and behavioral patterns, but the species seems to be selective and restricted to a group of potential prey in each region (Oliveira et al. 2008). The results of our study are consistent with those of BeL'Kovich et al. (1991), who emphasized that the feeding behavior of a species can vary according to habitat characteristics, prey species and their distribution.

According to MAJOR (1978), the feeding strategies of most cetaceans aim to reduce the size of the school and disorientate the fish, facilitating prey capture. Assuming that during wall formation, the dolphins in the group move in opposite directions to divide the school and capture prey, this feeding tactic seems to be the most efficient among $S$. guianensis populations. Among all of the coordinated tactics observed in this study, the wall formation was the most frequently used in both areas, showing that $S$. guianensis has clear preference for this tactic, suggesting that it yields the best cost-benefit ratio for all individuals involved.

The results of this comparative study suggest a possible convergence in feeding behavior for delphinids because the coordinated feeding tactics observed here are not exclusive to the species studied. Common dolphins, for instance Delphinus delphis (Linnaeus, 1758) in New Zealand, Neumann \& Orams (2003), also execute wall formation and line abreast formations, and BeL'коvich et al.'s (1991) also observed the kettle and wall formation in Black Sea bottlenose dolphins, T. truncatus.

Coordinated jumps had been previously reported for $S$. guianenis (e.g., Rossi-SANTOS \& Flores 2009). However, only TARDIN et al. (2011) have discussed the quantification and detailed investigation of these jumps. According to Acevedo-Gutierrez (1999), dolphins probably jump to drive fish against an obstacle. In the present study, jumps were frequent in the Ilha Grande Bay, whereas in the Sepetiba Bay they were rare. It is 
possible that differences in the depth of the water are responsible for this difference. In the Ilha Grande Bay, where the water level is shallower (about $10 \mathrm{~m}$ ), the impact of the dolphin's body against the water when returning from a jump up would be high and probably sufficient to disorient prey schools. It may also help to push prey against a dolphin barrier or the seabed, facilitating capture. The Sepetiba Bay has greater depths (about 30-40 m), and the intensity of the body impact would not cause a significant effect on prey. Another explanation may be the use of jumps as a method to signal the presence of prey to other groups (WÜrsIG \& WÜRSIG 1980).

The differences in the duration of the feeding bout, frequency of tactics and group size throughout seasons confirm a close association between predator and prey. A seasonal variability in the size of the group has been reported for several species of odontocetes in response to seasonal fluctuations in the habitat and the movements of potential prey (e.g., WürsIG \& WÜrsig 1980). According to Shane et al. (1986), there is a definite seasonal difference in the number of individuals in populations of species that remain in the same area throughout the year, which seems to be the case with these two populations of $S$. guianensis.

The size of a dolphins' group is associated with the size of the prey school, as observed by WÜRSIG \& WÜRSIG (1980), BENoIT-Bird \& Au (2009) and TARDin et al. (2011). The highest mean group size corresponded to the wall formation tactic in the two bays, as well as in the spring-summer season in the Ilha Grande Bay. The number of individuals engaged in this tactic is variable, from large groups in Ilha Grande, which may be associated to the capture of large schools (such as Engraulidae) that are abundant in the spring-summer season, to small groups in Sepetiba during the autumn-winter period, which may be explained by abundant small schools of the croaker, M. furnieri.

In the Ilha Grande Bay, the coordinated feeding bouts were longer, and tactics were more frequent of in the springsummer period. During this time, wall formation and perpendicular feeding were the most frequently observed tactics. Bay waters are strongly influenced by the SACW during the summer, which provides a great abundance of fish (SIGNORINI 1980). Thus, it is necessary to perform more coordinated tactics to catch prey in large schools, such as Cupleidae and Engraulidae, during this period (Matsuura 1978). Despite the fact that $S$. brasiliensis occurs in both areas, Paiva \& MotTA (2000) reported that the larger and heavier schools of species near the state of Rio de Janeiro were found in waters of the Ilha Grande Bay, corroborating our hypothesis. However, in the Sepetiba Bay, the duration of feeding bouts and the frequency of feeding tactics were higher during the autumn-winter period, with the wall formation and kettle being more frequently used during this season. Araújo et al. (1998) demonstrated that M. furnieri was one of the most abundant fish species in the bay in the autumn-winter period, which may influence the higher fre- quency of coordinated feeding tactics, such as kettle, during this season. The croaker (M. furnieri) is an abundant demersal species. This habit may be the reason why the kettle tactic occurs in the autumn-winter period in the Sepetiba Bay. Moreover, kettle occurred at greater depths (Neumann \& Oramns 2003). Information about M. furnieri is deficient for the Ilha Grande Bay. The similarities in prey composition and abundance in the Ilha Grande and Sepetiba bays have not been determined and more details must be gathered to better support this hypothesis.

Immature individuals were frequent during the coordinated feeding behavior in both areas. According to SHANE (1990), learning has an important role in the behavior of T. truncatus. By watching their mothers and other adults, the calves learn where and how to locate and capture prey.

Because the Sepetiba Bay is semi-enclosed and more protected, we expected that immature individuals (calves and juveniles) would be more frequent in the population of this bay. Contrasting with our expectations, we found that immature individuals are more frequent in the Ilha Grande Bay. One possible explanation is that calves and juveniles are more protected from human impacts in the Ilha Grande Bay than in the Sepetiba Bay (De Souza Lima et al. 2002) and consequently have more opportunities for learning coordinated tactics. Anthropogenic influences are more obvious in the Sepetiba Bay, of which intense boat traffic and a major harbor are good examples. Most likely, these factors also affect the availability of resources there. In conclusion, the Ilha Grande Bay seems to be more suitable to shelter a large dolphin population and therefore a larger number of infants.

The present study compares the largest populations found for the species $S$. guianensis and provides details on the coordinated feeding tactics of dolphins by quantifying the presence of calves and associated events in feeding tactics. The estuarine complex should be considered an important area for the conservation of this species, requiring greater management and preservation efforts. Knowledge of this subject is considered insufficient by IUCN (2004). Additional studies of coordinated behavior among other populations along the Brazilian coast are necessary to better understanding the ecology of this species.

\section{ACKNOWLEDGMENTS}

We sincerely thank Sergio C. Moreira from the Instituto Aqualie for helping with the elaboration of the map of the study area; William Rossiter for the financial support provided by the Cetacean Society International (CSI); and many trainee students from the Laboratório de Bioacústica e Ecologia de Cetáceos/DCA, Universidade Federal Rural do Rio de Janeiro (UFRRJ). Rodrigo H. Tardin is part of the Programa de Pós Graduação em Ecologia e Evolução, Universidade do Estado do Rio de Janeiro. Elaine C.S. Oliveira is part of the Programa de Pós-Graduação em Biologia Animal, UFRRJ. This study was 
partially supported by the Fundação de Amparo à Pesquisa do Estado do Rio de Janeiro (FAPERJ) (R.H.O. Tardin, Grant number E-26/151.047/2007 and E-26/100.866/2011) and the Coordenação de Aperfeiçoamento de Pessoal de Nível Superior (CAPES) (R.H.O. Tardin and E.C. da S. Oliveira).

\section{LITERATURE CITED}

Acevedo-Gutierrez, A. 1999. Aerial behavior is not a social facilitator in bottlenose dolphins hunting in small groups. Journal of Mammalogy 80 (3): 768-776.

Altmann, J. 1974. Observational study of behavioral sampling methods. Behaviour 69 (1): 227-267.

Araújo, G.F.; G.A. Cruz-Filho; C.C.M. Azevêdo \& A.C.A. Santos. 1998. Estrutura da Comunidade de Peixes Demersais da Baía de Sepetiba, RJ. Revista Brasileira de Biologia 58 (3): 417-430.

BAIRD, R.W. 2000. The killer whale: foraging specializations and group hunting, p. 127-153. In: J. ManN; R.C. ConNoR; P.L. TyACK; H. Whitehead (Eds). Cetacean Societies: Field studies of dolphins and whales. Chicago, University of Chicago Press, 448p.

BeL'Kovich, V.M.; E.E. Ivanova; O.V. YefremenKova; L.B. Kozarovitsky \& S.P. Kharitonov. 1991. Searching and hunting behavior in the bottlenose dolphin (Tursiops truncatus) in the Black Sea, p. 38-67. In: K. PrYor \& K.S. NorRIs (Eds). Dolphin societies: Discoveries and puzzles. Berkeley, University of California Press, 397p.

Benoit-Bird, K. J. \& W.W. Au. 2009. Prey herding by pelagic dolphins. Journal of the Acoustical Society of America 125 (1): 125-137

Borobia, M. \& N.B. Barros. 1989. Notes on the diet of marine Sotalia fluviatilis. Marine Mammal Science 5 (4): 395-399.

CARR, T. \& R.K. BONDE. 2000. Tucuxi (Sotalia fluviatilis) occurs in Nicaragua, $800 \mathrm{~km}$ north of its previously known range. Marine Mammal Science 16 (2): 447-452.

De Souza Lima, R.G.; F.G. Araújo; M.F. Maia \& A.S.S.B. Pinto. 2002. Evaluation of heavy metals in fish of the Sepetiba and Ilha Grande bays, Rio de Janeiro, Brazil. Environmental Research, Section A 89: 171-179.

Di Beneditto, A.P.M. \& R.M.A. Ramos. 2004. Biology of the marine tucuxi dolphin (Sotalia fluviatilis) in south-eastern Brazil. Journal of the Marine Biological Association of the United Kingdom 84 (6): 1245-1250.

Flach, L.; P.A. Flach \& A.G. Chiarello. 2008. Aspects of behavioral ecology of Sotalia guianensis in Sepetiba Bay, southeast Brazil. Marine Mammal Science 24 (1): 503-515.

Flores, P.A.C. \& V.M.F. DA Silva. 2009. Tucuxi and Guiana dolphin (Sotalia fluviatilis and Sotalia guianensis), p.1188-1192. In: W.F. Perrin; B. WÜrsig \& J.G.M. Thewissen (Eds). Encyclopedia of Marine Mammals. New York, Elsevier, 1316p.

GeIse, L. 1991. Sotalia guianensis (Cetacea, Delphinidae) population in the Guanabara Bay, Rio de Janeiro, Brasil. Mammalia 55 (3): 371-379.
Geise, L; N. Gomes \& R. Cerqueira. 1999. Behavior, habitat use and population size of Sotalia fluviatilis (Gervais, 1853) (Cetacea, Delphinidae) in the Cananéia estuary region, São Paulo, Brazil. Revista Brasileira de Biologia 59 (2): 183-194.

IUCN. 2004. Red List of Threatened Species. Gland, IUCN, 217p.

Karczmarski, L.; V.G. Cockcroft \& A. Mclachlan. 2000. Habitat use and preferences of Indo-pacific humpback dolphins Souza chinensis in Algoa Bay, South Africa. Marine Mammal Science 16: 64-79.

LoDI, L. 2003. Tamanho e composição dos grupos de botoscinza, Sotalia guianensis (van Bénéden, 1864) (Cetacea, Delphinidae), na Baía de Paraty, Rio de Janeiro, Brasil. Atlântica 25 (2): 135-146.

Lusseau, D. 2006. Why do dolphins jump? Interpreting the behavioural repertoire of bottlenose dolphins (Tursiops $s p$.) in Doubtful Sound, New Zealand. Behavioural Processes 73 (1): 257-265.

MAJOR, P.F. 1978. Predator-prey interactions in two schooling fishes, Caranx ignobilis and Stolephorus purpureus. Animal Behaviour 26 (3): 760-777.

MatsuURA, Y. 1978. Exploração e avaliação de estoque de peixes pelágicos no sul do Brasil - Projeto integrado para o uso e exploração racional do ambiente marinho. São Paulo, Instituto Oceanográfico, Relatório Técnico, 46p.

Monteiro-Filho, E.L.A. 2000. Group organization of the dolphin Sotalia fluviatilis guianensis in an estuary of southeastern Brazil. Ciência e Cultura 52 (2): 97-101.

Muehe, D. \& E. Valentini. 1998. O litoral do Rio de Janeiro: uma caracterização físico-ambiental. Rio de Janeiro, Femar, 123p.

Nascimento, L.F. \& S. V.M.M. Nascimento. 2010. Por que os botos, baleias e golfinhos saltam? Uma revisão das hipóteses explicativas sobre os saltos. Oecologia australis 14 (4): 821-829.

Nery, M.F.; M.A. EsPéCIE \& S.M. SimÃo. 2008. Site fidelity of Sotalia guianensis (Cetacea: Delphinidae) in Sepetiba Bay, Rio de Janeiro, Brazil. Revista Brasileira de Zoologia 25 (2): 182-187.

Neumann, D.R. \& M.B. Orams. 2003. Feeding behaviours of shortbeaked common dolphins, Delphinus delphis, in New Zealand. Aquatic Mammals 29 (1): 137-149.

Nogara, P.J. 2000. Caracterização dos ambientes marinhos da Área de Proteção Ambiental de Cairuçu - Município de Paraty - RJ. Rio de Janeiro, Fundação SOS Mata Atlântica, Technical report, 83p.

Oliveira, M. R. DE; F.C.W. Rosas; P.C. Pinheiro \& R.A. SANTOS. 2008. Alimentação, p. 147-160. In: E.L.A. Monteiro-Filho \& K.D.K.A. Monteiro (Eds). Biologia, Ecologia e Conservação do BotoCinza. Campinas, IPEC 274p.

Paiva, M.P. \& P.C.M. MotTA. 2000. Cardumes da sardinha-verdadeira, Sardinella brasiliensis (Steindachner), em águas costeiras do estado do Rio de Janeiro, Brasil. Revista Brasileira de Zoologia 17 (2): 339-346.

Rossi-Santos M.R \& L.L Wedekin. 2006. Evidence of bottom contact behavior by estuarine dolphins (Sotalia guianensis) 
on the eastern coast of Brazil. Aquatic Mammals 32 (2): 140-144.

Rossi-Santos, M.R. \& P.A.C. Flores. 2009. Feeding strategies of the Guiana dolphins Sotalia guianensis. The Open Marine Biology Journal 3 (7): 70-76.

Rossi-Santos, M.R.; L.L. Wedekin \& E.L.A. Monteiro-Filho. 2007. Residence and site fidelity of Sotalia guianensis in the Caravelas River Estuary, eastern Brazil. Journal of the Marine Biological Association of the United Kingdom 87 (1): 207-212.

SHANE, S.H. 1990. Comparison of bottlenose dolphin behavior in Texas and Florida, with a critique of methods for studying dolphin behavior, p. 541-558. In: S. LEatherwood \& R.R. ReEves (Eds). The bottlenose dolphin. San Diego, Academic Press, 653p.

ShANe, S.H.; R.S. Wells, \& B. WÜrSIG. 1986. Ecology, behavior and social organization of the bottlenose dolphin: a review. Marine Mammal Science 2 (1): 34-63.

SignoRINI, S.R. 1980. A study of the circulation in bay of Ilha Grande and bay of Sepetiba. Part I, an assessment to the tidally and wind-driven circulation using a finite element numerical model. Boletim do Instituto Oceanográfico 29 (1): 41-55.

SimÕES-Lopes, P.C. 1998. Ocorrência de uma população de Sotalia fluviatilis Gervais, 1853, (Cetacea: Delphinidae) no Limite Sul da sua distribuição, Santa Catarina, Brasil. Biotemas 1 (1): 57-62.
Smolker, R.A.; A.F. Richards; R.C. Connor \& J.W. Pepper. 1992. Sex differences in patterns of association among Indian Ocean bottlenose dolphins. Behaviour 123 (1-2): 38-69.

Tardin, R.O.H.; M.A. EsPecie; M.F. Nery; F.T. D'azeredo \& S.M. SIMÃo. 2011. Coordinated feeding tactics of the Guiana dolphin, Sotalia guianensis (Cetacea: Delphinidae), in Ilha Grande Bay, Rio de Janeiro, Brazil. Revista Brasileira de Zoologia 28 (3): 291-296.

TARdin, R.H.O.; M.A. EsPécIE \& S.M. Simão. 2013a. Parental care behavior in the Guiana dolphin, Sotalia guianensis (Cetacea: Delphinidae), in Ilha Grande bay, Southeastern Brazil. Zoologia 30 (1):15-23.

Tardin, R.H.; C.G. Galvão; M.A. Espécie, \& S.M. SimÃo. 2013 b. Group structure of Guiana dolphins, Sotalia guianensis (Cetacea, Delphinidae), in Ilha Grande Bay, Rio de Janeiro, Southeastern Brazil. Latin American Journal of Aquatic Research 41 (2): 313-322.

Vaughn, R.L.; B.WÜrsig; D.S. Shelton; L.L. Timm \& L.A. Watson. 2008. Dusky dolphins influence prey accessibility for seabirds in Admiralty Bay, New Zealand. Journal of Mammalogy 89 (4): 1051-1058.

WÜRSIG, B. \& M.WÜRSIG. 1980. Behavior and ecology of the dusky dolphin, Lagenorhynchus obscurus, in the South Atlantic. Fishery Bulletin 77 (4): 871-890.

Submitted: 27.V.2013; Accepted: 01.IX.2013.

Editorial responsibility: Paulo da Cunha Lana 